\title{
Correlação entre métodos de aleitamento, hábitos de sucção e comportamentos orofaciais $* * * *$
}

\author{
Correlation between feeding methods, non-nutritive sucking and \\ orofacial behaviors
}

Ana Paula Magalhães Medeiros*

José Tarcísio Lima Ferreira**

Cláudia Maria de Felício***

*Fonoaudióloga. Mestranda pela Faculdade de Medicina de Ribeirão Preto da Universidade de São Paulo (USP).

**Cirurgião Dentista. Doutor em Engenharia Metalúrgica e Materiais Biomateriais pelo Instituto Alberto Luiz Coimbra de Pós-Graduação e

Pesquisa de Engenharia da Universidade Federal do Rio de Janeiro. Professor do Departamento de Clínica Infantil, Odontologia Preventiva e Social da Faculdade de Odontologia de Ribeirão Preto - USP.

***Fonoaudióloga. Doutora em Ciências pela USP. Professora do Departamento de Oftalmologia, Otorrinolaringologia e Cirurgia de Cabeça e Pescoço - Área

Fonoaudiologia da Faculdade de Medicina de Ribeirão Preto da USP Endereço para correspondência: Av. Bandeirantes, 3900 - Ribeirão Preto - SP - CEP 14049-900

(cfelicio@fmrp.usp.br).

****Trabalho Realizado nas Faculdades de Medicina e Odontologia de Ribeirão Preto da Universidade de São Paulo.

Artigo Original de Pesquisa

Artigo Submetido a Avaliação por Pares

Conflito de Interesse: não

Recebido em 16.02.2009.

Revisado em 10.09.2009; 28.10.2009.

Aceito para Publicação em 28.10.2009.

\begin{abstract}
Background: the development of oral motor control depends partially on motor and sensory experiences. Aim: to analyze the relationship between the duration of breastfeeding, artificial feeding and sucking habits, and of these parameters with the orofacial motor performance. Method: participants of this study were one hundred and seventy-six children aged 6 to 12 years. All subjects were submitted to an orofacial myofunctional clinical examination, using a protocol with scores, and parents/care takers were interviewed in respect to the feeding and sucking habits of their children. Correlations were calculated using the Spearman Test. Results: in the studied sample, the mean duration of breastfeeding was of 10.30 months (ranging from zero to 60 months), of artificial feeding was of 44.12 months (zero to 122 months) and of sucking habits was of 39.32 months ( 0 to 144 months). There was a negative correlation of breastfeeding duration with artificial feeding duration and sucking habits duration $(\mathrm{p}<0001)$. The duration of the artificial feeding was positively correlated to the duration of sucking habits $(p<0001)$. The duration of breastfeeding was positively correlated with the mobility of the tongue and jaw $(\mathrm{p}=0.05)$. There was a negative correlation of the duration of artificial feeding and the duration of sucking habits with the performance in mastication and swallowing, respectively, as well as with the duration of both types of sucking with the performance in the diadochokinesia test $(\mathrm{p}=0.05)$. Conclusion: the duration of natural breastfeeding presented a positive effect over the mobility of the orofacial structures. Deleterious effects of the prolonged duration of artificial feeding and sucking habits in the oral motor control were confirmed. Key Words: Breastfeeding; Habits; Stomatognathic System; Motor Skills.
\end{abstract}

\section{Resumo}

Tema: o desenvolvimento do controle motor oral depende em parte das experiências sensoriais e motoras. Objetivo: analisar a relação entre a duração do aleitamento natural, artificial e da sucção e destas com o desempenho motor orofacial. Método: cento e setenta e seis crianças, de 6 a 12 anos de idade, passaram por avaliação miofuncional orofacial, empregando o protocolo com escores, e os responsáveis foram entrevistados a respeito do aleitamento e hábitos de sucção de suas crianças. As correlações foram calculadas pelo teste de Spearman. Resultados: na amostra estudada, a média de duração do aleitamento natural foi de 10,30 meses (variando de zero a 60 meses), do aleitamento artificial 44,12 (zero a 122 meses) e dos hábitos de sucção de 39,32 meses (zero a 144 meses). Houve correlação negativa da duração do aleitamento natural com a duração do aleitamento artificial e a duração dos hábitos de sucção (p < 0,001). A maior duração do aleitamento artificial correspondeu à maior duração dos hábitos de sucção, apresentando, assim, correlação positiva $(\mathrm{p}<0,001)$. A duração do aleitamento natural foi correlacionada positivamente com a mobilidade orofacial $(\mathrm{p}=0,05)$. Houve correlação negativa da duração do aleitamento artificial e da duração dos hábitos de sucção com, respectivamente, o desempenho na mastigação e na deglutição, bem como da duração de ambos os tipos de sucção com a prova de diadococinesia $(\mathrm{p}=0,05)$. Conclusão: a duração do aleitamento natural mostrou efeito positivo sobre a mobilidade das estruturas orofaciais. Os efeitos deletérios da duração dos hábitos de sucção no controle motor orofacial foram confirmados.

Palavras-Chave: Aleitamento Materno; Hábitos; Sistema Estomatognático; Diadococinesia.

Referenciar este material como:

$\Omega$ Medeiros APM, Ferreira JTL, Felício CM de. Correlation between feeding methods, non-nutritive sucking and orofacial behaviors (original title: Correlação entre $\sum 3$ métodos de aleitamento, hábitos de sucção e comportamentos orofaciais ). Pró-Fono Revista de Atualização Científica. 2009 out-dez;21(4):315-9. 


\section{Introduction}

Orofacial motor control evolves from marked movement instability to more stable movements (1) and from undifferentiated movements to a differentiated and synchronized control of orofacial structures which depends on the maturation of the nervous system, on musculoskeletal growth and on sensorimotor experiences (2).

Among the experiences of a baby, breast-feeding is particularly important since it prevents alterations in the craniofacial complex (3-5). Factors such as time and frequency of breast-feeding, of artificial feeding and of non-nutritive sucking habits can influence orofacial development (6) and, when negative, they can provoke instability of orofacial function and malocclusion $(7,8,9,4,10,11,12)$.

In the speech therapy area, studies of the effects of type of feeding and of sucking habits on craniofacial growth and development involve the analysis of orofacial myofunctional disorders in a given population in relation to its sucking history $(6,13)$.

The objective of the present study was to investigate the relation between the duration of breast-feeding and of sucking habits (pacifier and/ or finger sucking) and between these variables and children's performance quantified by means of scores in tasks of orofacial structure mobility, diadochokinesia and mastication and swallowing functions.

\section{Method}

The study was approved by the Human Research Ethics Committee of the Faculty of Medicine of Ribeirão Preto, University of São Paulo, Process $n^{\circ} .3376 / 2006$. The persons responsible for the children were informed about the objectives and methods of the study and gave written consent for data collection and publication of the results.

The participants were 176 children ( 85 boys and 91 girls) aged 6 to 12 years on a waiting list for various dental treatments.

The inclusion criteria were: to be a native Brazilian Portuguese speaker and to present no specific complaint of communication.

The exclusion criteria were: to present hearing loss, mental retardation, neurological or emotional disorders and craniofacial malformations, previous or current tumors or traumas in the head and neck region, and orthodontic treatment as determined by examination of the medical records and by anamnesis.

\section{Data collection}

Anamnesis was performed with the persons responsible for the children in order to obtain the information necessary for the study, such as identification, age and data regarding health and development, and feeding and oral habit history.

\section{Orofacial myofunctional evaluation}

The children were evaluated individually by the same examiner using the protocol of orofacial myofunctional evaluation with scores (OMES) (14). The evaluation was performed by visual inspection during the session and was later complemented by the analysis of images recorded on videocassette.

The subjects sat on a chair with a back support, with their feet resting on the floor. The distance between the subject and the tripod lens and height was standardized.

The components of the stomatognathic system were evaluated in terms of mobility and performance during mastication and deglutition - liquid and solid -functions.

For the evaluation of mobility, the children were asked to perform the following movements:

. lips: protrusion, retrusion, lateral to the right and left.

. tongue: protrusion, retrusion, lateral to the right and left, raising, and lowering and ability to keep the tongue in stable protrusion for 5 seconds;

. mandible: protrusion, lowering, raising, lateral to the right and left.

In the analysis, separate movements of each component, precise and without tremors, were considered to be normal. Dysfunction was considered to be present when lack of precision in the movement, tremor, associated movements of other components (e.g., lips accompanying the movements of the tongue) and inability to perform the movement were observed.

According to the OMES Protocol (14), the examiner attributed scores on a 3 point scale: $3=$ normal, 2 = insufficient ability, and $1=$ absence of ability or being unable to perform the task.

To complement the analysis, for jaw movements, extension measurements (in $\mathrm{mm}$ ), symmetry/ asymmetry during mouth opening and closing, and right and left laterality and protrusion were also considered (15).

For deglutition, the pattern was considered to be normal when the subject presented the tongue 
contained in the oral cavity, contraction of elevator muscles, and anterior sealing of the oral cavity without effort. When some disorder of swallowing, adaptation or atypia occurred, the affected muscles and/or actions were recorded.

For mastication, the subject was instructed to chew a stuffed Bono® cookie in his habitual manner, and the examiner observed trituration, the presence of associated body movements and possible food escape.

In the analysis of images recorded on video, the following parameters were considered:

. chewing, whether alternate bilateral, simultaneous bilateral, chronic unilateral (95\% of the time on the same side of the oral cavity), or anterior; unilateral chewing preference ( $66 \%$ of the time on the same side), or anterior, . total time needed to consume the food: the chronometer was always started after the placement of food in the oral cavity and the beginning of trituration, and was stopped when the final swallowing of each portion occurred.

Scores were later attributed according to the protocol.

\section{Diadococinesia}

The stimulus used was /pataka/. It was explained to the child that she or he should try to repeat the stimulus as fast as possible without making mistakes. The model was first given by the examiner using stimuli different from those to be given in the test. The child imitated the examiner and the test was then started.

The repetitions were interrupted by the examiner after 3 seconds. The samples were audiorecorded and the number of complete repetitions emitted within 3 seconds was later counted (1). The productions were recorded on a cassette audiotape with a Panasonic RQ-L11Mini Cassette Recorder and speech rate was then calculated using a digital chronometer (Cronobios).

\section{Data analysis}

The software STATISTICA (StatSoft Inc., Tulsa, Oklahoma, USA) was used for statistical analysis of the data. The mean duration of nutritive sucking and of sucking habits was calculated. The correlation between duration of breast-feeding and duration of sucking habits, as well as the correlation between these variables and motor performance, were calculated by the Spearman correlation test. The level of significance was set at $\mathrm{p}<0,05$.

\section{Results}

The sample consisted of some children who had been exclusively breast-fed and others who had ben exclusively fed artificially since birth. Most of the children had received both types of feeding, i.e., natural and artificial (Table 1).

The duration of breast-feeding was negatively correlated with the duration of artificial feeding $(r=$ $-0.33, \mathrm{p}<0,001)$ and with the duration of sucking habits $(\mathrm{r}=-0.27, \mathrm{p}<0.001)$. The duration of artificial feeding was positively correlated with the duration of sucking habits $(r=0.23, p<0.001)$, i.e., the longer the duration of artificial feeding, the longer the duration of sucking habits, with the opposite being also true.

There was a positive and significant correlation between the duration of natural feeding and tongue $(r=0.17, p<0.05), \operatorname{lip}(r=0.15 . p<0.05)$ and mandible (mouth opening in $\mathrm{mm})(\mathrm{r}=0.23 \mathrm{p}<0.01)$ mobility. The following negative and significant correlations were observed: duration of artificial feeding with masticatory performance $(\mathrm{r}=-0.18 . \mathrm{p}<0.05)$ and with the diadochokinesia test $(r=-0.16 . p<0.05)$; duration of sucking habits with swallowing function $(\mathrm{r}=-0.16 . \mathrm{p}<0.05)$ and with the diadochokinesia test $(\mathrm{r}=-0.20 . \mathrm{p}<0.05)$. The duration of sucking habits tended to be significantly correlated with tongue mobility $(\mathrm{r}=-0.14 . \mathrm{p}=0.057)$. Table 2 presents the correlation coefficients for the variables, including those that were not significant. 


\section{Discussion}

In the present study we analyzed the correlations between the duration of natural and artificial breast-feeding and of sucking habits and their correlation with orofacial motor performance assessed by means of a validated protocol (14).

Previous studies in the speech therapy area have shown significant relations between sucking and orofacial behaviors $(4,6,13,16)$. However, the analyses are usually performed by association considering the frequencies of orofacial myofunctional disorders, i.e., considering the presence or absence of the latter, a fact that does not permit the measurement of orofacial motor performance or correlation analyses.

Orofacial growth and development depend on the correct performance of all stomatognathic functions. Thus, breast-feeding is important by generating adequate neural stimuli and consequently preventing orofacial myofunctional disorders (5). The positive correlation detected in the present study between natural feeding and the mobility of orofacial structures (lips, mandible and tongue) confirms this statement.

The duration of natural feeding was negatively correlated with the duration of artificial feeding and the duration of sucking habits. Early weaning leads to the introduction of artificial feeding, which may be prolonged for a longer time than needed to satisfy the nutritional needs of the infant and which is often associated with sucking habits $(17,18)$, as also detected in the present sample.

When a baby receives natural feeding fir more than 4 months, the tendency to the development of sucking habits is lower (19) than when the baby receives exclusive artificial feeding. The artificial method may also result in a longer duration of sucking habits (20).

The negative correlations detected in the present study between the duration of artificial feeding and masticatory performance, and between the duration of sucking habits and swallowing function, as well as the correlation between these two factors (artificial feeding and suction habits) and performance in the diadochokinesia test confirm that inadequate stimuli over long periods of time may impair the stomatognathic functions $(4,21,16)$ and the orofacial motor control. This creates difficulties in the evolution to more stable movements (1) and in the differentiated and synchronized control of orofacial structures (2).

The diadochokinesia tests evaluate the ability to produce various repetitions of relatively simple patterns of opposite contractions and can provide information about maturation, neuromotor integration (22) and the development of speaking skills (23).
TABLE 1. Descriptive analysis of sucking regarding the percentage of subjects and the duration of each type.

\begin{tabular}{|c|c|c|c|c|}
\hline & Subjects & \multicolumn{3}{|c|}{$\begin{array}{l}\text { Duration } \\
\text { (months) }\end{array}$} \\
\hline Feeding & $\%$ & Mean & Mar & mum \\
\hline Natural & 10.23 & 36 & & \\
\hline Artificial & 7.950 & 48 & & 0 \\
\hline $\begin{array}{l}\text { Natural and artificial } \\
\text { (mixed) }\end{array}$ & 81.82 & 47 & 42 & 126 \\
\hline Sucking habits & 69.32 & 35.89 & & 4 \\
\hline
\end{tabular}

* Percentage of the total of 172 children

TABLE 2. Correlation coefficients between variables and levels of significance.

\begin{tabular}{llll}
\hline $\mathrm{N}=176$ & \multicolumn{2}{c}{ Duration of feeding } & $\begin{array}{c}\text { Duration of } \\
\text { Sucking } \\
\text { Habits }\end{array}$ \\
& Natural & Artificial & \\
\hline $\begin{array}{l}\text { Duration } \\
\text { Artificial feeding }\end{array}$ & $-0.33^{* * * *}$ & & \\
NNS Habit & $-0.27^{* * *}$ & $0.23^{* *}$ & \\
Mobility & & & \\
Lips & $0.15^{*}$ & -0.040 & -0.05 \\
Tongue & $0.17^{*}$ & -0.14 & -0.14 \\
Mandible & $0.23^{* *}$ & -0.09 & -0.04 \\
Functions & & & \\
Mastication & 0.09 & $-0.18^{*}$ & 0.03 \\
Swallowing & 0.04 & 0.08 & $-0.16^{*}$ \\
$\begin{array}{l}\text { Diadochokinesia } \\
\text { PATAKA/sec }\end{array}$ & 0.08 & $-0.16^{*}$ & $-0.20^{* * *}$ \\
\hline
\end{tabular}

Mandible mobility $=$ mouth opening in $\mathrm{mm}$. Spearman Correlation Test Significant at the $5 \%$ level $=*, 1 \%=* *, 0.1 \%=* * *, 0.001=* * * *$ $\mathrm{NNS}=$ non-nutritional sucking

The present study confirmed that the lack of natural feeding for a period of time considered to be sufficient and the prolongation of artificial feeding and of sucking habits may compromise oral motor development. Thus, this is still a problem that deserves attention in order to promote health.

The adoption of guidance procedures (24) and the association of orofacial myofunctional therapy have proved to be beneficial in order to interrupt sucking habits and to promote oral health (12). 


\section{Conclusion}

On the basis of the present study, it was possible to conclude that the longer duration of natural feeding had a positive influence on the mobility of orofacial structures in the sample under study, whereas the negative correlations of the duration of artificial feeding and of sucking habits with

\section{References}

1. Robbins J, Klee T. Clinical assessment of oropharingeal motor development in young children. J. Speech Hear Disord. 1987;52(3):271-7.

2. Green JR, Moore CA, Higashikawa M, Steve RW. The physiologic development of speech motor control: lip and jaw coordenation. J. Speech Lang Hear Res. 2000;43:23955 .

3. Boiron M, Nobrega L Da, Roux S, Henrot A, Saliba E. Effects of oral stimulation and oral support on non-nutritive sucking and feeding performance in preterm infants. Developmental Medicine \& Child Neurology. 2007; 49(6):439-44

4. Neiva FCB, Cattoni DM, Ramos JLA, Issler H. Desmame precoce: implicações para desenvolvimento motor oral. J. Pediatr. 2003;79(1):7-12.

5. Viggiano D, Fasano D, Monaco G, Strohmenger LB Breast feeding, bottle feeding, and non-nutritive sucking effects on occlusion in deciduous dentition. Arch. Dis. Child 2004;89(12):1121-3.

6. Wadsworth SD, Maul CA, Stevens EJ. The prevalence of orofacial myofunctional disorders among children identified with speech and language disorders ingrades kindergarten through six. Int. J. Orofac. Myol. 1998;24:1-19.

7. Adair SM, Milano M, Lorenzo I. Effects of current and fomer pacifies use on the dentition of 24 to 59 month old children. Pediatr. Dent. 1995;17(7):437-44.

8. Charchut SW, Allred EN, Needleman HL. The effects of infant feeding patterns on the oclusion of the primary dentition. J Dent Child. 2003;70(3):197-203.

9. Felício CM, Ferreira-Jeronymo RR, Ferriolli BHVM, Freitas RLRG. Análise da associação entre sucção, condições miofuncionais orais e fala. Pró-Fono 2003;15(1):31-40.

10 Luz CL, Garib DG, Arouca R. Association between breastfeeding duration and mandibular retrusion: a crosssectional study of children in the mixed dentition. Am J Orthod Dentofac Orthop. 2006;130(4):531-4.

11. Katz CRT, Rosemblatt A, Gondin PPC. Nonnutritive Sucking habits in Brazilian children: effects on deciduous dentition and relationship with facial morphology. Am J Orthod Dentofac Orthop. 2004; 126(1):53-7.

12. Degan VV, Puppin-Rontani RM. Removal of sucking habits and myofunctional therapy: establishing swallowing and tongue rest position. Pro-Fono. 2005;17(3):375-82. masticatory and swallowing function and the diadochokinesia test confirmed the deleterious effects of these factors on the orofacial motor control.
13. Winocur E, Gavish A, Finkelshtei, T, Halachmi, M, Gazi, E. Oral habits among adolescent girls and their association with symptoms of temporomandibular disorders. J. Oral Rehabil. 2001;28(7):624-629.

14. Felício CM, Ferreira CLP: Protocol of orofacial myofunctional evaluation with scores. Int $\mathrm{J}$ Pediatr Otorhinolaryngol. 2008;72:367-375.

15. Felício CM. Fonoaudiologia aplicada a casos odontológicos: motricidade oral e audiologia. $1^{\text {a }}$ ed. São Paulo: Pancast; 1999.

16. Subtelny J. Malocclusions, orthodontic corrections and orofacial muscle adaptation. Angle Orthod. 1970;40:170201.

17. Bošnjak A, Vucicevic-Boras V, Miletic I, Božic D, Vukelja M. Incidence of oral habits in children with mixed dentition. J. Oral Rehabil. 2002;29(9):902-5.

18. Victora CG, Behague DP, Barros FC, Olinto MTA, Weiderpass E. Pacifier use and short breastfeeding duration: cause, consequence, or coincidence? Pediatrics. 1997;99(3):445-53.

19. Mizuno K, Ueda A. Development of sucking behavior in infants who have not been fed for 2 months after birth Pediatrics International. 2001;43( 3)251-5.

20. Ogaard B, Larsson E, Linstein R. The effect of sucking habits, cohort, sex, intercanine arch widths, and breast or bootle feeding on posterior crossbite in noruwegian and sMwedish 3 year old children. Am. J. Orthod. Dentofacial Orthop. 1994;106(2)161-6

21. Ganesh M, Tandon S, Sajida B. Prolonged feeding practice and its effects on developing dentition. J. Indian Soc. Pedod. Prev. Dent. 2005;23(3)141-5.

22. Baken RJF, Orlikoff R. Speech movements: In: Clinical measurement of speech and voice. Ed. San Diego: SingularThompson Learning; 2000.

23. Yaruss JS, Logan KJ. Evaluating rate, accuracy, and fluency of Young children's diadochokinetic productions: a preliminary envestigation. J Fluency Disord 2002;27:6586.

24. Melsen B, Stensgaard K, Pedersen J. Sucking habits and their influence on swallowing pattern and prevalence of malocclusion. Eur. J. Othodont. 1979;1(4):271-80. 